\author{
EWA WITEK*), EDGAR BORTEL, KATARZYNA GAWEŁEK \\ Jagiellonian University \\ Faculty of Chemistry \\ ul. R. Ingardena 3, 30-060 Kraków, Poland
}

\title{
On some aspects concerning solution-suspension polymerization of $N$-vinylformamide**)
}

\begin{abstract}
Summary - N-vinylformamide (NVF), a blocked vinylamine monomer, has become an important reagent in the synthesis of water-soluble resins. NVF can be easily polymerized in aqueous solutions, in bulk, in suspension and by means of emulsions techniques. In the present paper an advantage was taken of the poor solubility of poly( $N$-vinylformamide) (PNVF) in organic solvents and a solution/precipitation polymerization was investigated. Toluene was used as a solvent for NVF. Polymerizations were carried out in three series differing by the type of initiator and temperature. In series I 2,2'-azobis(isobutyronitryle) (AIBN) was used, replaced in series II with benzoyl peroxide (BP) and in series III with a redox system BP/N,N-dimethylamino- $p$-toluidine (BP/DMAT). Optimal temperatures in series I and II were found to be $50^{\circ} \mathrm{C}$ and $80^{\circ} \mathrm{C}$, respectively, whereas in series III the possibility was tested to polymerize at the room temperature $\left(22^{\circ} \mathrm{C}\right)$. At increasing initiator to monomer molar ratios outputs were growing up to $98 \%$ in series I and II while simultaneously times of the cloud point appearances have become shorter. However, there is no distinct relation between molar masses of and initiator concentration. It is noteworthy that for all polymers obtained by the solution/precipitation technique all dispersity values were below 2 what is not so easy to achieve with other techniques.
\end{abstract}

Keywords: $N$-vinylformamide, solution-suspension polymerization, free radicals initiators.

\section{NIEKTÓRE ASPEKTY POLIMERYZACJI ROZPUSZCZALNIKOWO-SUSPENSYJNEJ N-WINY- LOFORMAMIDU}

Streszczenie - N-winyloformamid (NVF), z zablokowanymi grupami winyloaminowymi, jest ważnym monomerem $\mathrm{w}$ syntezie żywic rozpuszczalnych $\mathrm{w}$ wodzie. Polimeryzację NVF można bez trudu realizować $w$ roztworze wodnym, w masie, w suspensji oraz techniką emulsyjną. W prezentowanej pracy wykorzystano słabą rozpuszczalność poli( $N$-winyloformamidu) (PNVF) w rozpuszczalnikach organicznych i badano rozpuszczalnikowo-strąceniową polimeryzację NVF. Jako rozpuszczalnik NVF stosowano toluen. Wykonano trzy serie polimeryzacji wobec różnych inicjatorów i w różnych temperaturach. W Serii I stosowano 2,2'-azobis(izobutyronitryl) (AIBN), który w Serii II zastąpiono nadtlenkiem benzoilu (BP), a w Serii III układem redoksowym BP/N,N-dimetyloamino- $p$-toluidyna (BP/DMAT). Jako optymalne temperatury w Serii I i Serii II przyjęto odpowiednio $50^{\circ} \mathrm{C}$ i $80^{\circ} \mathrm{C}$, w Serii III badano możliwość polimeryzacji w temperaturze pokojowej $\left(22^{\circ} \mathrm{C}\right)$. Stwierdzono, że ze wzrostem stosunku molowego inicjatora do monomeru wzrasta i to aż do wartości 98 \% w Serii I i Serii II wydajność reakcji, a jednocześnie skraca się czas, po którym pojawia się zmętnienie. Nie zaobserwowano wyraźnej zależności pomiędzy stężeniem stosowanego inicjatora a wartością masy molowej otrzymanego polimeru. Należy podkreślić, że stopień dyspersji masy molowej $\left(\bar{M}_{w} / \bar{M}_{n}\right)$ wszystkich polimerów otrzymanych na drodze polimeryzacji rozpuszczalnikowo-strąceniowej był mniejszy niż 2. Jest to trudne do uzyskania z zastosowaniem innych metod polimeryzacji.

Słowa kluczowe: $\mathrm{N}$-winyloformamid, polimeryzacja roztworowo-suspensyjna, inicjatory wolnorodnikowe.

\footnotetext{
*) Correspondence author; e-mail: witek@chemia.uj.edu.pl

**) Material contained in this article was presented at the 7th Congress of Chemical Technology, Cracow, Poland, 8-12 July 2012.
}

\section{INTRODUCTION}

The great expectancy which came up at the beginning of the current century, when $\mathrm{N}$-vinylformamide (NVF) 
appeared on the marked as an industrial product, ceased somewhat in the following years due to the recognition of the scarcity of solvents, confining reactions of NVF and its polymers mainly to water. As a consequence, chemical modifications of copolymerization with hydrophobic monomers, suspension polymerizations etc. proved to be more difficult [1].

There are attempts to circumvent these difficulties. Recently a precipitative copolymerization has been described for NVF with acrylic acid, as well as for methacrylic acid in isopropanol [2] under circumstances in which the classic theory of copolymerization cannot be applied to determine copolymerization constants. A way out was found by a choice of proper solvents.

In accordance with recently published paper [3] a procedure was worked out and described which enables to functionalize NVF with such hydrophobic and bulky substituents like 4-methoxybenzylchloride, (bromomethyl)cyclohexane, 1-chloro-2-methylbutane, and many others. The problem is to select adequate solvents.

NVF is a reactive monomer with very good polymerizability. The preferred kind of polymerization in case of NVF is the radical one according to the equation:

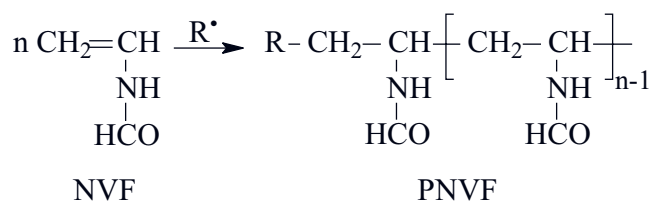

After polymerization and hydrolysis it offers an extremely high ionic content in the resulting polyvinylamine $[4,5]$. It should be noticed, that cationic polyelectrolytes are exploited now in many fields. Relative to other monomers, like acrylamide (AAm) NVF with its reverse amide structure, it is regarded to be nontoxic [6].

According to recent literature data [7], potato starch grafted with NVF enhances starch hydrophilicity bringing its desired solubility in water.

It was only in the past decade that an industrial production of the blocked vinylamine monomer began [8], rendering via poly $(\mathrm{N}$-vinylformamide) (PNVF) a precursor for synthesis of polyvinylamine (PVAm). It is to say, however, that PVAm does not contain exclusively $\mathrm{NH}_{2}$ function groups attached to the backbone. The acidic hydrolysis of PNVF is confined to a ca. $80 \%$ conversion and hence a remarkable part of $\mathrm{NHCHO}$ groups remains unchanged [9]. On the other hand, the alkaline hydrolysis converts the formamide groups completely, but according to our own findings [10] not all of them become $\mathrm{NH}_{2}$ groups. A lower part is converted to $\mathrm{OH}$ groups.

One disadvantage of NVF as a monomer is the confinement of molar masses to the range between 5000 and $500000 \mathrm{~g} / \mathrm{mol}$ which is easy to obtain [11]. For many applications like flocculation, higher molar masses are desirable. Some authors have published results of investigations using PNVF, the molar masses of which were beyond the $10^{6} \mathrm{~g} / \mathrm{mol}$ limit [12]. However, these were samples isolated by dialysis from a set of macromolecules differing in degree of polymerization. A membrane was used with a $10^{6} \mathrm{~g} / \mathrm{mol}$ molar mass cutoff to remove low molecular species and impurities [13].

A further disadvantage of PNVF is its poor solubility in organic solvents. Most solvents other than water, e.g. tert- $\mathrm{BuOH}$, toluene, isopropanol, and mixtures of them do not dissolve the homopolymer of NVF.

$\mathrm{N}$-vinylformamide is polymerized in bulk, solution and in emulsion $[14,15]$. In bulk polymerization the main problem concerns stabilization of temperature. As soon as the degree of conversion reaches $20 \%$ the Trommsdorf effect (of autoacceleration) takes place. In solution polymerization by far the best solvent is water, but difficulties come about when copolymerization is attempted with non water-soluble comonomers. In the case of suspension and emulsion polymerization techniques [6] the resulting polymer needs a troublesome purification which most often is not complete.

The chemical properties and non-toxicity of PNFV and PVAm resulted in a broad range of industrial applications such as paper making [16-18], adhesives [19, 20], ink jet printing [21], textile chemicals [22], biomedical products [23, 24], flocculants [25] etc. That reflects the importance these polymers have already gained. Nevertheless, many problems have not yet been elucidated satisfactorily. For example, to the best of our own knowledge, the solution/precipitation polymerization of NVF was never investigated before more closely.

Therefore, our investigations described in this paper were focused on solution/precipitation homopolymerization of NVF with the aim to learn how the parameters employed influence the characteristics of the resulting polymer. The variable factors are initiator to monomer mole ratio, kind of initiator, temperature and time of polymerization.

\section{EXPERIMENTAL}

\section{Materials}

$\mathrm{N}$-vinylformamide (NVF, Aldrich Chem. Co.) was argon vacuum distilled $\left(80^{\circ} \mathrm{C}, 1600 \mathrm{~Pa}\right) .2,2^{\prime}$-Azobis(izobutyronitril) (AIBN, Fluka), dibenzoiloperoxide (BP, Argon, Lódź), N,N-dimethylamino-p-toluidine (DMAT, Aldrich Chem. Co.) were used without further purification. Solvents like methanol, toluene (both from POCh, Gliwice) were purified by distillation before use. Water was deionized and subsequently distilled.

\section{Polymerization procedure}

All polymerizations were performed in carefully dried glassware, under a purified argon atmosphere. Toluene $\left(c a .50 \mathrm{~cm}^{3}\right)$ was placed in a polymerization flask $\left(250 \mathrm{~cm}^{3}\right)$ equipped with a gas inlet and reflux condenser. 
Freshly distilled monomer (NVF) was added in amount $35 \mathrm{mmol}(2.5 \mathrm{~g})$ and then warmed up to the desired reaction temperature $\left(22,50\right.$ or $80{ }^{\circ} \mathrm{C}$ ) and simultaneously purged with argon. Then the respective initiator ( $\mathrm{I}=$ AIBN, BP or BP/DMAT) dissolved in an adequate amount of toluene $\left(1-9 \mathrm{~cm}^{3}\right)$ was added. The stop-watch was started to measure the time needed to achieve the cloud point $\left(\tau_{c l}\right)$. The polymerization feed was agitated by purge of argon.

As soon as the precipitation ceased to be perceptible the reaction was interrupted by cooling the flask with its content. Since only a part of the polymer sedimented immediately, after its isolation $100 \mathrm{~cm}^{3}$ of methanol was mixed into the vessel to coagulate the remaining suspension. The entire deposited polymer was filtered and again suspended in $100 \mathrm{~cm}^{3}$ of methanol and once more filtered. This operation was repeated tree times to remove any adhering toluene. In the end the polymer was vacuum dried to achieve a constant mass. Temperatures of polymerization $(t)$ were constant, but in each series they were different.

\section{Methods of investigations}

The molar masses and dispersity of the molecular weight of water soluble NVF homopolymers were determined by aqueous size exclusion chromatography/multi-angle laser light scattering (SEC/MALLS). The separation was performed in two serially connected SEC columns: GMPWXL $(300 \times 7.8 \mathrm{~mm})$ and TSK gel 2500 PWXL $(300 \times 7.8 \mathrm{~mm})$ (both from Tosoh Corporation, Tokyo, Japan). The columns were connected to a multi-angle laser light scattering detector (Dawn-DSP-F, Wyatt Technology) and a differential refractive index detector (L-7490, Merck, Darmstadt, Germany). A salt aqueous solution $\left(0.05 \mathrm{M} \mathrm{NaNO}_{3}\right)$ was used as the eluting solvent for measurements. The flow rate of the mobile phase was $0.5 \mathrm{~cm}^{3} / \mathrm{min}$. The output voltages of the refractive index (n) detector and light scattering intensities at 18 angles were collected and used to calculate number-average molar mass $\left(\bar{M}_{n}\right)$, weight-average molar mass $\left(\bar{M}_{w}\right)$, and mass dispersity $\left(\bar{M}_{w} / \bar{M}_{n}\right)$ of the obtained polymers, using Astra 4.50 software (Wyatt Technology). Calculations were made using the Zimm function. Refractive index increment $(\mathrm{d} n / \mathrm{d} c)$ for PNVF in $0.05 \mathrm{M} \mathrm{NaNO}_{3}$ aqueous solution was determined to be $0.1373 \mathrm{~cm}^{3} / \mathrm{g}(\lambda=690 \mathrm{~nm})$. All chromatograms of the investigated polymers were monomodal.

The yield of polymerization $(Y)$ was determined gravimetrically using the relation:

$$
Y=\frac{m_{p}}{m_{0}} \cdot 100 \%
$$

where: $m_{0}-$ mass of monomer taken to polymerization, $m_{p}-$ mass of the vacuum dried polymer obtained.

\section{RESULTS AND DISCUSSION}

Poor solubility of PNVF in organic solvents can be utilized advantageously for polymerization of its monomer by means of the solution precipitation technique. In preliminary investigations we found toluene to be the best suited organic solvent among the few which dissolve NVF at all.

The investigations were carried out in tree series, differing with the temperature and time of polymerization and the type of used initiator (I). Within this series the effect of the amount of the initiator on the yield of polymerization and molar mass dispersity was examined. The results of these investigations are presented in Table 1. In series I AIBN was employed as an initiator. It is well known from literature [11] that azo-compounds are best suited for starting polymerization of NVF. However, the temperature of such a polymerization must hold the most favorable range between 50 and $80^{\circ} \mathrm{C}$. Below that range no cloud point was to be seen what meant that AIBN could not be employed at the room temperature. That was the reason for our attempts to investigate two further initiators, i.e. $\mathrm{BP}$ and the redox system set up by BP/DMAT with molar ratio 3:1 in favor of BP.

Results listed in Table 1 reflect regularities existing within each of the three series, which regularities are

T a b l e 1. Conditions and results of NVF; meaning of symbols: $c_{I}\left(\mathrm{mmol} / \mathrm{dm}^{3}\right)-$ concentration of the initiator, $\mathrm{I} / \mathrm{NVF}-\mathrm{molar} \mathrm{ratio}$ of the initiator to monomer, $\mathrm{t}\left({ }^{\circ} \mathrm{C}\right)-$ polymerization temperature, $\tau_{\mathrm{pol}}(\mathrm{h})-$ polymerization time

\begin{tabular}{|c|c|c|c|c|c|c|c|c|c|}
\hline Series conditions & $\begin{array}{l}\text { Amount } \\
\text { of I, mol }\end{array}$ & $\begin{array}{c}c_{I} \\
\mathrm{mmol} / \mathrm{dm}^{3}\end{array}$ & $\begin{array}{l}\mathrm{I} / \mathrm{NVF} \\
\mathrm{mol} / \mathrm{mol}\end{array}$ & $\tau_{c l}, \mathrm{~s}$ & $Y, \%$ & $\begin{array}{c}\bar{M}_{n} \cdot 10^{-3} \\
\mathrm{~g} / \mathrm{mol}\end{array}$ & $\begin{array}{c}\bar{M}_{w} \cdot 10^{-3} \\
\mathrm{~g} / \mathrm{mol}\end{array}$ & $\bar{M}_{w} / \bar{M}_{n}$ & $\begin{array}{l}\text { Symbol of } \\
\text { the polymer } \\
\text { obtained }\end{array}$ \\
\hline \multirow{4}{*}{$\begin{array}{l}\text { Series I }- \text { AIBN } \\
t=50^{\circ} \mathrm{C}, \tau_{p o l}=5 \mathrm{~h}\end{array}$} & 0.175 & 3.5 & 0.005 & 483 & 50 & 284.6 & 328.0 & 1.45 & PNVF-I-1 \\
\hline & 0.350 & 7.0 & 0.010 & 283 & 85 & 158.9 & 212.7 & 1.34 & PNVF-I-2 \\
\hline & 0.700 & 14.0 & 0.020 & 214 & 98 & 129.4 & 228.5 & 1.88 & PNVF-I-3 \\
\hline & 1.600 & 32.0 & 0.055 & 173 & 98 & 239.2 & 239.2 & 1.40 & PNVF-I-4 \\
\hline \multirow{2}{*}{$\begin{array}{c}\text { Series II - BP } \\
t=80^{\circ} \mathrm{C}, \tau_{p o l}=4 \mathrm{~h}\end{array}$} & 0.175 & 3.5 & 0.005 & 44 & 87 & 66.2 & 113.5 & 1.72 & PNVF-II-5 \\
\hline & 1.600 & 32.0 & 0.055 & 21 & 98 & 59.6 & 67.1 & 1.13 & PNVF-II-6 \\
\hline \multirow{3}{*}{$\begin{array}{c}\text { Series III }- \text { BP/DMAT } \\
t=22{ }^{\circ} \mathrm{C}, \tau_{p o l}=72 \mathrm{~h}\end{array}$} & 0.175 & 3.5 & 0.005 & 4515 & 27 & 60.4 & 77.7 & 1.29 & PNVF-III-7 \\
\hline & 0.350 & 7.0 & 0.010 & 755 & 42 & 41.8 & 49.6 & 1.19 & PNVF-III-8 \\
\hline & 0.700 & 14.0 & 0.020 & 270 & 40 & 14.3 & 18.1 & 1.27 & PNVF-III-9 \\
\hline
\end{tabular}


commonly inherent in radical polymerizations performed in bulk and in solutions. At the constant temperature and with the same initiator the decisive factor is molar ratio of initiator to monomer (I/NVF ratio). With increasing I/NVF value $\tau_{c l}$ decreased and $Y$ becomes greater. In regard to average molar masses $\bar{M}_{n}$ and $\bar{M}_{w}$ it can be seen that the solution precipitation polymerization of NVF does not guarantee extra high degrees of polymerization. By far the best results in all investigated samples were obtained in series I, where AIBN was used as initiator. Here the molar masses $\bar{M}_{n}$ are between $284.6 \cdot 10^{3}$ and $129.4 \cdot 10^{3} \mathrm{~g} / \mathrm{mol}$ and dispersities are between 1.34 and 1.88 .

The employment of $\mathrm{BP}$ in series II required $80{ }^{\circ} \mathrm{C}$ as the temperature of polymerization because otherwise the yields were small. Molar masses are lower than in series I.

In series III the aim was to check the possibility to accomplish the solution precipitation polymerization of NVF at the room temperature $\left(22^{\circ} \mathrm{C}\right)$ using a redox system for initiation, i.e. BP/DMAT. The attempt failed. After $72 \mathrm{~h}$ of the reaction time only a small amount of the polymer were formed, and against expectation, its molar mass appeared to be relatively small, below the $100 \cdot 10^{3} \mathrm{~g} / \mathrm{mol}$. Results listed in Table 1 confirm the inferiority of peroxide initiators in radical polymerization of NVF. It is to recognize that by the choice of a proper initiator the possibility exists to regulate the molar masses within higher or lower ranges.

The solution precipitation polymerization requires that the resulting polymer was stepwise isolated from its solution while the process is going on. That makes a difference to solution polymerization in which side reactions are more likely to occur.

Common for both the solution and solution precipitation polymerizations is the need to purify the synthesized polymers carefully from the solvent used. In the case of PNVF we found methyl alcohol to be more suitable for that purpose than acetone, which renders the flocks after coagulation more sticky.

Noteworthy is the fact that for all prepared polymers i.e. for series PNVF-I to PNVF-III, the mass dispersities were found to be below 2 . That is not so easy to achieve by applying other techniques of radical polymerization.

\section{ACKNOWLEDGMENT}

This work was supported by Ministry of Science and Higher Education, grant No N204 354840.

\section{REFERENCES}

1. Pinschmidt R. K. Jr., Wasowski L. A., Orphamides G. G., Yacoub K.: Progr. Org. Coat. 1996, 27, 209.

2. Gavrilova J. J., Panarin E. F.: Russ. J. Chem. 2009, 82, 618.

3. Ajiro H., Akasi M.: J. Polym. Sci. Part A: Polym. Chem. 2012, 50, 134

4. Yamamoto K., Imamura Y., Nagatomo E., Serizawa T., Muraoka Y., Akashi M.: J. Appl. Polym. Sci. 2003, 89, 1277.

5. Pinschmidt R. K. Jr.: J. Polym. Sci. Part A: Polym. Chem. 2010, 48, 2257.

6. Pinschmidt R. K. Jr., Renz W. L., Caroll W. E., Yacoub K., Drescher J., Nordquist A. F., Chen N.: J. Macromol. Sci. 1997, A34, 1885.

7. Spychaj T., Schmidt B., Ulfig K., Markowska-Szczupak A.: Polimery 2012, 57, 95.

8. Korner M., Dubois J., Winter M.: J. Pract. Chem. 2000, 342, 115.

9. Gu L., Zhu S., Hrymak A. N.: J. Appl. Polym. Sci. 2002, 86, 3412.

10. Witek E., Pazdro M., Bortel E.: J. Macromol. Sci. 2007, A44, 503.

11. Spange S., Madl A., Eismann U., Utecht J.: Macromol. Rapid Comm. 1997, 18, 1075.

12. Badesco R. J., Lei T. W., Pinschmidt R. K., Jr. Sagl D. J., Vijanyndran B. R.: Polym. Prep. 1991, 32, 110.

13. Marhefka J. N., Marascalco P. J., Chapman T. M., Russell A. L., Kameneva M. V.: Biomacromolecules 2006, 7, 1597.

14. Gu L., Zhu S., Hrymak A. N., Pelton R. H.: Polymer 2000, 42, 3077.

15. Yamamoto K., Imamura Y., Nagatomo E., Serizawa T., Muraoka Y., Akashi M.: J. Appl. Polym. Sci. 2003, 89, 1277.

16. Pelton R., Hong J.: Tappi J. 2002, 1, No. 10, 21.

17. Diflavio J.-L., Pelton R., Leduc M., Champ S., Essig M., Frechen T.: Cellulose 2007, 14, 257.

18. US Patent Application US 2011/0 247775 A1.

19. Chen W., Leung V., Kroener H., Pelton R.: Langmuir 2009, 25, 6863.

20. Treusch O. G., Petutschingg A.: BioResources 2012, 7, 789.

21. US Patent Application US 2012/0 069084 A1.

22. Pat. USA 6823650 (2004).

23. Tang Ch., Kligman F., Larsen C. C., Kottke-Marchant K., Marchant R. E.: J. Biomed. Mater. Res. A. 2009, 88, 348.

24. Scorilas A., Bjartell A., Lilja H., Moller Ch., Diamandis E. P.: Clinical Chem. 2000, 46, 1450.

25. Ubowska A., Spychaj T.: Polimery 2010, 55, 299.

Received 12 VII 2012. 